\title{
Е.Л. Матвеев
}

\section{ЭКОЛОГИЧЕСКИЙ КОНТРОЛЬ ЗАГРЯЗНЕННОСТИ АТМОСФЕРНОГО ВОЗДУХА НА ОБЪЕКТАХ АВИАТОПЛИВООБЕСПЕЧЕНИЯ}

\begin{abstract}
Рассмотрены вопросы необходимости организауии экологической политики на уровне авиапредприятия с иелью снижепия неблагоприятного воздействия антропогенной нагрузки иа окружаючую среду, уменъиения неблагоприятного влияния авиачионных горюче-смазочных материалов (ГСМ) на безопасность труда, снижения уровня потерь нефтепродуктов на авиапредприятии.
\end{abstract}

Известно, что Украина относится к регионам с высоким уровнем развития инфраструктуры производства, транспортировки, потребления и переработки нефти и нефтепродуктов. По количеству “технической грязи" на душу населения наша страна занимает перво место в Европе и имеет самый низкий показатель продолжительности жизни (66 лет) сред стран бывшего СССР [1].

Закон Украины “О экологической экспертизе", предусматривает регулирование общественньгх отношений в области экологических исследований, в том числе оценки объектов, деятельность которых негативно влияет на состояние окружающей среды и здоровье людей. К таким объектам, несомненно, относятся предприятия авиатопливообеспечения. И необходимость экологического контроля здесь вполне очевидна, так как сушествуют:

- выбросы паров нефтепродуктов при заполнении резервуаров и температурных колебаниях их газового пространства, т.е. при "больших" и "малых" дыханиях резервуаров;

- испарения нефтепродукгов с поверхности почвы и наземных покрытий при авариях, утечках, а также с поверхности сточных вод;

- продукты зачистки резервуаров и технологических трубопроводов, негерметичны емкости для сбора отстоя топлива, отработанных нефтепродуктов;

- выбросы вредных веществ в результате эксплуатации как подвижных средств авиационной наземной техники, так и воздушных судов (количество токсичных компонентов, получаемых при сгорании некоторых топлив, приведено в таблице).

Борьба с загрязнением окружаюшей среды на сегодняшний день требует довольно значительных средств, что часто порождает мнение о чрезмерно завышенных суммах на сохранение чистоты окружающей среды. Однако проведенный анализ отечественных и зарубежньх исследований показал, что затраты на борьбу с загрязнением во много раз меньше, че экономический ущерб от загрязнения.

Кроме этого, объективно созрела необходимость формирования экологической политики на уровне авиапредприятия. Теоретической базой такой политики может служить концепция риска, ядро которой - здоровье работающих, несомненно имеющего причинноследственную связь с обеспечением высокого уровня безопасности полетов и, в свою очередь, безопасной эксплуатации авиационной техники. Данная концепция предусматривае учет не только традиционных и известных загрязнителей и источников риска, а и малозаметньх, но потенциально опасных факторов и процессов.

К настоящему времени накоплено множество факторов, свидетельствующих о существовании зависимости между степенью загрязнения атмосферного воздуха и состоянием здоровья. Так, например, для работников, связанньгх с нефтепродуктами, это изменения сердечно-сосудистой и нервной системы, повышенная заболеваемость органов дыхания [3] 
Количество токсичных компонентов, которые выбрасываются в атмосферу при сгорания 1 кг топлива, r [2]

\begin{tabular}{|l|c|c|}
\hline \multirow{2}{*}{ Компонент } & \multicolumn{2}{|c|}{ Вид топлива } \\
\cline { 2 - 3 } & Бензин & Дизельное топливо \\
\hline Монооксид углерода & 465,59 & 20,81 \\
\hline Углеводороды & 23,28 & 4,16 \\
\hline Оксиды азота & 15,83 & 18,01 \\
\hline Ангидрид серной кислоты & 1,86 & 7,80 \\
\hline Альдегиды & 0,93 & 0,78 \\
\hline Сажа & 1,0 & 5,0 \\
\hline Свинец & 0,5 & - \\
\hline Всего & 508,99 & 51,56 \\
\hline
\end{tabular}

На сегодняшний день уже достаточно исследованы негативные последствия влияния на здоровье атмосферных загрязнений, вибрации, шума и т.п. Безопасно допустимое воздействие каждого из данных факторов соответствующим образом нормировано в виде предельнодопустимых концентраций (ПДК), предельнодопустимых уровней (ПДУ) и т.п. Однако на практике, в частности на объектах авиатопливообеспечения, на работающих действуют одновременно такие факторы, как: пониженная или повышенная подвижность воздуха; пониженная или повышенная температура и влажность воздуха; повышенная концентрация паров вредныг вешеств; повышенные уровни шума, вибрации и т.д. Вредное воздействие паров нефтепродуктов усиливается при сочетанном их действии с физическими факторами [4]. Позтому возникает необходимость проведения соответствуюцего мониторинга и исследований объектов авиатопливообеспечения с целью регулирования времени нахождения работающих в опасной зоне на основе существующих нормативов и результатов проводимых нами исследований, а также корректировки норм ПдК в будущем.

В этой связи была разработана программа "ЭкоавиаГСМ", которая прежде всего направлена на практическое решение проблем снижения неблагоприятного влияния ГСМ на работников, улучшение экологической ситуации авиапредприятия, уменьшение потерь нефтепродуктов при их транспортировке, хранении, выдаче.

Один из разделов программы связан с обеспечением чистоты воздуха рабочей зоны. Критерием оценки неблагоприятного влияния авиаГСМ на безопасность труда и окружающую среду авиапредприятия служит концентрация загрязнения воздуха рабочей зоны парами нефтепродуктов.

Разработанная в связи с этим методика оценки неблагоприятного действия авиаГСМ на человеческий фактор предусматривает следующее. 
1. Проведение в рабочих зонах предприятия дополнительных уточненных замеров загрязненности воздуха на предмет содержания углеводородов, окислов азота, серы и т.п. Для этого предполагается проведение экспрессной оценки содержания органических соединений в воздухе рабочих зон при помощи использования автоматических переносных газоанализаторов типа "Марс", которые позволяют одновременно автоматически оценить и контролировать объемную долю $\mathrm{NO}, \mathrm{NO}_{2}, \mathrm{CO}, \mathrm{SO}_{2}$ с основной приведенной погрешностью измерений любой газовой компоненты $\pm 10 \%$.

2. Комплексную оценку уровня состояния атмосферного воздуха рабочих зон с использованием индекса загрязнения атмосферы (ИЗА, I $)$ ), что позволяет охарактеризовать вклад отдельных компонентов в общий уровень загрязнения атмосферы за определенный период времени на данной территории или в данной точке:

$$
I_{3}=\sum_{i=1}^{n}\left(\frac{q_{i}}{\Pi \not K_{\mathrm{cc} i}}\right)^{C_{i}}
$$

где $q_{i}$ - средняя за год концентрация примеси; ПДК мая концентрация примеси; $\mathrm{C}_{i}$ - безразмерная константа, позволяющая привести степень вредности $i$-го вещества к степени вредности двуокиси серы.

Ранжирование по выбросам вредных веществ с целью определения наиболее опасной зоны работы для служащих конкретного авиапредприятия.

Проведение корректировки времени работы (времени нахождения в опасной зоне) на основе существующих нормативов и результатов проводимых нами исследований в области оценки неблагоприятного сочетанного воздействия на работающего таких факторов, как пары вредных веществ, производственный шум, вибрация, а также особенностей условий труда на конкретном производстве, что позволит повысить качественный показатель работ, связанный с обеспечением безопасности полетов а также снизить уровень заболеваемости и выплаты по временной нетрудоспособности.

Разработка технико-технологических рекомендаций по снижению потерь нефтепродуктов и выбросов вредных веществ в атмосферу.

Таким образом, использование предлагаемых методик позволит оценить экологическую ситуацию на объектах авиатопливообеспечения, предпринять соответствующие меры по снижению неблагоприятного воздействия антропогенной нагрузки на окружаюшую среду, уменьшить неблагоприятное влияние авиаГСМ на безопасность труда, снизить уровень потерь нефтепродуктов на предприятии.

\section{Список литературы}

1. Державні науково-технічні програми: Звіти за 1994 р. /Державний комітет з питань науки і технологій. - К.: Вип.2: Охорона навколишнього природного середовища. - 1995. $152 \mathrm{c}$.

2. Даценко I.I., Денисюк. О.Б. Сучасні проблеми гігієни навколишнього середовищаю Львів: Держ. мед. Університет, 1997. - 136 с.

3. Костюк I.Ф., Капусник В.А. Професійні хвороби. - Харків: Основа, 1998. - 400 с.

4. Umеренгари P.Я. Токсико-гигиенические аспекты сочетанного действия на организм химических и физических факторов производственной среды: Автореф. дис... д-ра мед. наук. - М.: $1991-48$ с. 